\title{
Effect of perioperative blood transfusion on prognosis of patients with gastric cancer: a retrospective analysis of a single center database
}

Xiaowen Liu ${ }^{1,2+}$, Mingze Ma ${ }^{1,2+}$, Hua Huang ${ }^{1,2}$ and Yanong Wang ${ }^{1,2^{*}}$

\begin{abstract}
Background: The association between perioperative blood transfusion and the prognosis of patients with gastric cancer is still unclear.

Methods: A total of 1581 patients with gastric cancer who underwent curative gastrectomy from 2000 to 2008 were evaluated. Perioperative blood transfusion was defined as the transfusion of packed red blood cells within seven days before surgery, during surgery, or within the postoperative hospitalization period. The association between perioperative blood transfusion and prognosis was evaluated using univariate and multivariate Cox regression analyses.

Results: Of 1581 patients, 298 patients (19\%) received perioperative blood transfusion. Perioperative blood transfusion correlated with older age $(P<0.001)$; larger tumor size $(P<0.001)$; and more advanced stage $(P<0.001)$. Five-year survival rate was $40 \%$ in patients who had perioperative blood transfusion and $55 \%$ patients who did not have perioperative blood transfusion, and the difference was statistically significant $(P<0.001)$. Multivariate analysis showed that perioperative blood transfusion was defined as independent prognostic factor. Perioperative blood transfusion was associated with worse outcomes in patients with stage III $(P<0.001)$.

Conclusions: Perioperative blood transfusion independently correlated with poorer prognosis in patients with gastric cancer.
\end{abstract}

Keywords: Gastric cancer, Perioperative blood transfusion, Prognosis

\section{Background}

Although the incidence of gastric cancer has declined, it is still the sixth most frequent cancer and the fourth most common cause of cancer death worldwide [1]. In the United States, most patients with gastric cancer are diagnosed at late stage [2]. Anemia is more likely to exist in patients with advanced gastric cancer. Some studies reported that up to $60 \%$ of patients presented with perioperative anemia, and most of them undergoing gastrectomy needed red blood cell transfusion [3, 4]. It is well-known that blood transfusions are associated with some adverse outcomes. In

\footnotetext{
* Correspondence: wangyn1111@hotmail.com

${ }^{+}$Xiaowen Liu and Mingze Ma contributed equally to this work.

'Department of Gastric Cancer Surgery, Fudan University Shanghai Cancer Center, 270 Dong An Road, Shanghai 200032, People's Republic of China

${ }^{2}$ Department of Oncology, Shanghai Medical College, Fudan University, Shanghai 200032, China
}

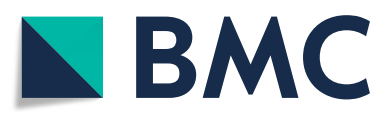

(c) The Author(s). 2018 Open Access This article is distributed under the terms of the Creative Commons Attribution 4.0 International License (http://creativecommons.org/licenses/by/4.0/), which permits unrestricted use, distribution, and reproduction in any medium, provided you give appropriate credit to the original author(s) and the source, provide a link to the Creative Commons license, and indicate if changes were made. The Creative Commons Public Domain Dedication waiver (http://creativecommons.org/publicdomain/zero/1.0/) applies to the data made available in this article, unless otherwise stated.

particular, some studies showed that blood transfusions were associated with an increased risk of postoperative morbidity [5, 6]. Additionally, some studies have shown that perioperative blood transfusion correlated with poor prognosis of patients with lung cancer, breast cancer, and colorectal cancer [7-9].

Although there have been some studies about the influence of perioperative blood transfusion on prognosis of patients with gastric cancer after undergoing curative gastrectomy, the results still remains controversial [10-13]. Two studies demonstrated that perioperative blood transfusion was associated with worse clinical outcomes for patients with gastric cancer underwent gastrectomy $[10,11]$. In contrast, some other studies have not shown worse outcomes $[12,13]$. 
The purpose of this study is to clarify the effect of perioperative blood transfusion on the prognosis of patients with gastric cancer by analyzing large retrospective sample from our institution.

\section{Methods}

\section{Patients}

From 2000 to 2008, 1581 patients with histologically confirmed primary gastric adenocarcinoma underwent curative gastrectomy. Perioperative blood transfusion was defined as the transfusion of packed red blood

Table 1 Patient Cohort

\begin{tabular}{|c|c|c|}
\hline & $n=1581$ & $100 \%$ \\
\hline \multicolumn{3}{|l|}{ Gender } \\
\hline Male & 1102 & 70 \\
\hline Female & 479 & 30 \\
\hline \multicolumn{3}{|l|}{ Age (yr) } \\
\hline$\leq 60$ & 891 & 56 \\
\hline$>60$ & 690 & 44 \\
\hline \multicolumn{3}{|l|}{ Tumor size (cm) } \\
\hline$\leq 5$ & 1136 & 72 \\
\hline$>5$ & 445 & 28 \\
\hline \multicolumn{3}{|l|}{ Tumor location } \\
\hline Upper third & 563 & 36 \\
\hline Middle third & 275 & 17 \\
\hline Lower third & 702 & 44 \\
\hline Two-third or more & 41 & 3 \\
\hline \multicolumn{3}{|l|}{ TNM stage } \\
\hline Stage I & 403 & 26 \\
\hline Stage ॥ & 382 & 24 \\
\hline Stage III & 796 & 50 \\
\hline \multicolumn{3}{|l|}{ Type of Gastrectomy } \\
\hline Subtotal & 1342 & 85 \\
\hline Total & 239 & 15 \\
\hline \multicolumn{3}{|l|}{ Operation time (min) } \\
\hline$<180$ & 1025 & 65 \\
\hline$\geq 180$ & 556 & 35 \\
\hline \multicolumn{3}{|c|}{ Albumin level at admission ( $\mathrm{g} / \mathrm{dl}$ ) } \\
\hline$<3.5$ & 379 & 24 \\
\hline$\geq 3.5$ & 1202 & 76 \\
\hline \multicolumn{3}{|c|}{ Hemoglobin level at admission (g/dl) } \\
\hline$<12$ & 575 & 36 \\
\hline$\geq 12$ & 1006 & 64 \\
\hline \multicolumn{3}{|c|}{ Perioperative blood transfusion } \\
\hline Yes & 298 & 19 \\
\hline No & 1283 & 81 \\
\hline
\end{tabular}

TNM Tumor Node Metastasis, $n$ number of patients, min minute cells within seven days before surgery, during surgery, or within the postoperative hospitalization period. Postoperative hospitalization is defined as the immediate postoperative period following surgery. Data were retrieved from operative and pathological reports, and follow-up data were obtained by phone, out-patient and clinical database [14]. Written

Table 2 Comparison of the clinicopathological characteristics of patients with perioperative blood transfusion and without perioperative blood transfusion

\begin{tabular}{|c|c|c|c|}
\hline Variables & $\begin{array}{l}\text { Group with } \\
\text { perioperative blood } \\
\text { transfusion } n=298\end{array}$ & $\begin{array}{l}\text { Group without } \\
\text { perioperative blood } \\
\text { transfusion } n=1283\end{array}$ & $P$ value \\
\hline Gender & & & 0.749 \\
\hline Male & 210 & 892 & \\
\hline Female & 88 & 391 & \\
\hline Age (yr) & & & $<0.001$ \\
\hline$\leq 60$ & 119 & 772 & \\
\hline$>60$ & 179 & 511 & \\
\hline Tumor size $(\mathrm{cm})$ & & & $<0.001$ \\
\hline$\leq 5$ & 148 & 988 & \\
\hline$>5$ & 150 & 295 & \\
\hline Tumor location & & & $<0.001$ \\
\hline Upper third & 116 & 447 & \\
\hline Middle third & 68 & 207 & \\
\hline Lower third & 95 & 607 & \\
\hline $\begin{array}{l}\text { Two-third or } \\
\text { more }\end{array}$ & 19 & 22 & \\
\hline TNM stage & & & $<0.001$ \\
\hline Stage I & 37 & 366 & \\
\hline Stage II & 84 & 298 & \\
\hline Stage III & 177 & 619 & \\
\hline $\begin{array}{l}\text { Type of } \\
\text { Gastrectomy }\end{array}$ & & & $<0.001$ \\
\hline Subtotal & 221 & 1121 & \\
\hline Total & 77 & 162 & \\
\hline $\begin{array}{l}\text { Operation time } \\
\text { (min) }\end{array}$ & & & 0.001 \\
\hline$<180$ & 168 & 857 & \\
\hline$\geq 180$ & 130 & 426 & \\
\hline $\begin{array}{l}\text { Albumin level at } \\
\text { admission (g/dl) }\end{array}$ & & & 0.001 \\
\hline$<3.5$ & 94 & 285 & \\
\hline$\geq 3.5$ & 204 & 998 & \\
\hline $\begin{array}{l}\text { Hemoglobin level } \\
\text { at admission }(\mathrm{g} / \mathrm{dl})\end{array}$ & & & $<0.001$ \\
\hline$<12$ & 211 & 364 & \\
\hline$\geq 12$ & 87 & 919 & \\
\hline
\end{tabular}


informed consent had been obtained from all the patients, and this study was approved by the Ethical Committee of Fudan University Shanghai Cancer Center. Staging was carried out according to the American Joint Committee on Cancer TNM (Tumor Node Metastasis) Staging Classification for Carcinoma of the Stomach (Seventh Edition, 2010).

\section{Follow-up}

The standard follow-up protocol for patients with gastric cancer was every three months for at least two years, every six months for the next three years, and after five years every 12 months for life [14]. The follow-up items were as follows: physical examination, tumor-marker examination, chest radiography, endoscopic examination, and computed tomographic scan.

\section{Statistical analysis}

The Chi-square test was used to analyze patients' features and clinicopathological characteristics. The Kaplan-Meier method was used to calculate five-year survival rate, and the long-rank test was used to examine the differences between survival curves. The prognostic factors were included into the multivariate survival analysis using Cox proportional hazards model. The level of significance was $P<0.05$. Statistical analyses and graphics were carried out using the SPSS 13.0 statistical package (SPSS, Inc., Chicago, IL).

\section{Results}

\section{Clinicopathological characteristics}

There were 1102 males and 479 females (2.3:1) with a mean age of 58 years. According to tumor location, 563 (36\%) had tumors located in the upper third; 275
(17\%) in the middle third; $702(44 \%)$ in the lower third, and 41 (3\%) occupied two-thirds or more of stomach. The distribution of pathological stage was as follows: 403 (26\%) patients had stage I, 382 (24\%) patients had II, and 796 (50\%) patients had III. Patients demographics were listed in Table 1.

Clinicopathologic parameters were compared between patients who underwent perioperative blood transfusion and who did not. Results showed that patients with perioperative blood transfusion presented at an older age $(P<0.001)$; larger tumor size $(P<0.001)$; and more advanced stage $(P<0.001)$ (Table 2$)$.

\section{Amount of blood transfusion}

Of the 1581 patients, 298 patients (19\%) received perioperative blood transfusion. With regard to period and amount of transfusion, 128 (43\%) patients received transfusion before operation, 215 (72\%) during the operation, and 119 (40\%) after the operation. 29 (10\%) patients received transfusion only before operation, 105 (35\%) only during the operation, and 35 (12\%) only after the operation; $134(45 \%)$ patients received less than 4 units, and 164 (55\%) patients received more than 4 units.

\section{Univariate analysis}

The median follow-up time was 60.2 months. The over-all five-year survival rate was $53 \%$ for all 1581 patients. Five-year survival rate was 40 and $55 \%$ in group with perioperative blood transfusion and group without perioperative blood transfusion, respectively, and the difference was statistically significant $(P<0.001)$ (Fig. 1). In addition to perioperative blood transfusion, significant prognostic factors included: age, tumor size,

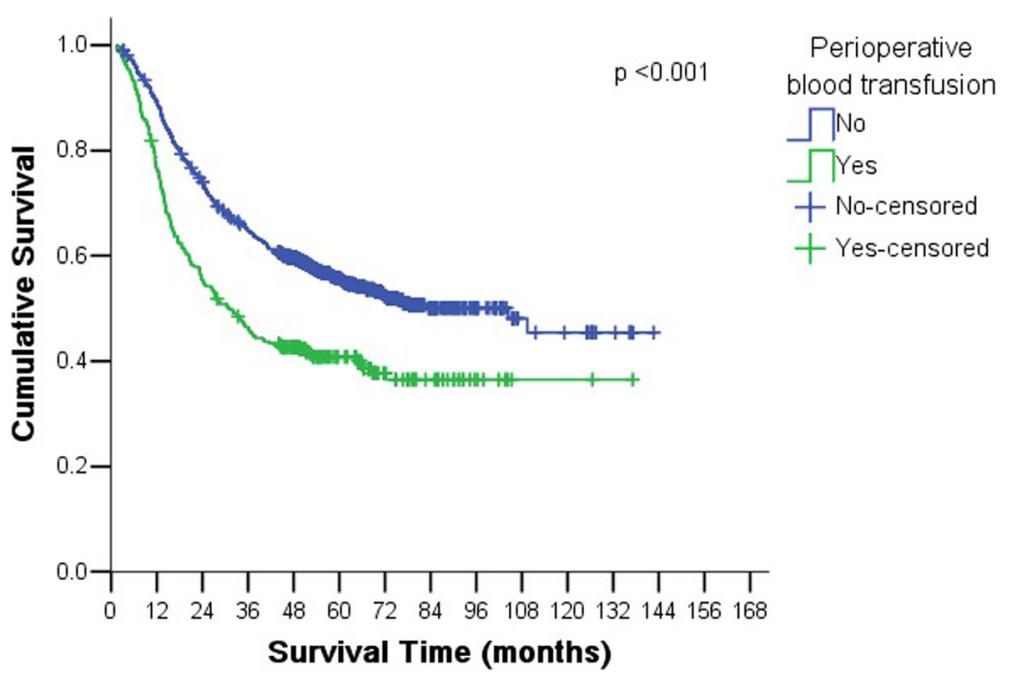

Fig. 1 There was significant difference in the survival between group with perioperative blood transfusion and group without perioperative blood transfusion 
tumor location, TNM stage, type of gastrectomy, operation time, albumin level at admission, and hemoglobin level at admission (Table 3). In patients with perioperative blood transfusion, univariate analysis showed that tumor location and TNM stage significantly affected prognosis, other factors like blood transfusion frequency and blood transfusion amount did not correlate with prognosis (Table 4).

Table 3 Univariate analysis of all patients

\begin{tabular}{|c|c|c|c|}
\hline & $\mathrm{n}$ & $\begin{array}{l}\text { 5-year survival } \\
\text { rate }(\%)\end{array}$ & $P$ value \\
\hline Gender & & & 0.759 \\
\hline Male & 1102 & 52 & \\
\hline Female & 479 & 53 & \\
\hline Age (yr) & & & $<0.001$ \\
\hline$\leq 60$ & 891 & 58 & \\
\hline$>60$ & 690 & 45 & \\
\hline Tumor size $(\mathrm{cm})$ & & & $<0.001$ \\
\hline$\leq 5$ & 1136 & 59 & \\
\hline$>5$ & 445 & 36 & \\
\hline Tumor location & & & $<0.001$ \\
\hline Upper third & 563 & 39 & \\
\hline Middle third & 275 & 49 & \\
\hline Lower third & 702 & 65 & \\
\hline Two-third or more & 41 & 32 & \\
\hline TNM stage & & & $<0.001$ \\
\hline Stage I & 403 & 94 & \\
\hline Stage II & 382 & 61 & \\
\hline Stage III & 796 & 27 & \\
\hline Type of Gastrectomy & & & $<0.001$ \\
\hline Subtotal & 1342 & 56 & \\
\hline Total & 239 & 34 & \\
\hline Operation time (min) & & & $<0.001$ \\
\hline$<180$ & 1025 & 58 & \\
\hline$\geq 180$ & 556 & 43 & \\
\hline Albumin level at admission (g/dl) & & & 0.006 \\
\hline$<3.5$ & 379 & 47 & \\
\hline$\geq 3.5$ & 1202 & 54 & \\
\hline Hemoglobin level at admission ( $\mathrm{g} / \mathrm{dl}$ ) & & & $<0.001$ \\
\hline$<12$ & 575 & 46 & \\
\hline$\geq 12$ & 1006 & 56 & \\
\hline Perioperative blood transfusion & & & $<0.001$ \\
\hline Yes & 298 & 40 & \\
\hline No & 1283 & 55 & \\
\hline
\end{tabular}

\section{Multivariate analysis}

Multivariate survival analysis was performed to determine the independent prognostic factors for patients with gastric cancer. Multivariate analysis showed that

Table 4 Univariate analysis of patients with perioperative blood transfusion

\begin{tabular}{|c|c|c|c|}
\hline & $n$ & $\begin{array}{l}\text { 5-year survival } \\
\text { rate (\%) }\end{array}$ & $P$ value \\
\hline Gender & & & 0.838 \\
\hline Male & 210 & 41 & \\
\hline Female & 88 & 39 & \\
\hline Age (yr) & & & 0.411 \\
\hline$\leq 60$ & 119 & 43 & \\
\hline$>60$ & 179 & 38 & \\
\hline Tumor size (cm) & & & 0.103 \\
\hline$\leq 5$ & 148 & 44 & \\
\hline$>5$ & 150 & 36 & \\
\hline Tumor location & & & 0.035 \\
\hline Upper third & 116 & 35 & \\
\hline Middle third & 68 & 35 & \\
\hline Lower third & 95 & 51 & \\
\hline Two-third or more & 19 & 32 & \\
\hline TNM stage & & & $<0.001$ \\
\hline Stage I & 37 & 89 & \\
\hline Stage II & 84 & 57 & \\
\hline Stage III & 177 & 22 & \\
\hline Type of Gastrectomy & & & 0.060 \\
\hline Subtotal & 221 & 42 & \\
\hline Total & 77 & 34 & \\
\hline Operation time (min) & & & 0.057 \\
\hline$<180$ & 168 & 45 & \\
\hline$\geq 180$ & 130 & 34 & \\
\hline $\begin{array}{l}\text { Albumin level at admission } \\
(\mathrm{g} / \mathrm{dl})\end{array}$ & & & 0.245 \\
\hline$<3.5$ & 94 & 35 & \\
\hline$\geq 3.5$ & 204 & 42 & \\
\hline $\begin{array}{l}\text { Hemoglobin level at admission } \\
(\mathrm{g} / \mathrm{dl})\end{array}$ & & & 0.655 \\
\hline$<12$ & 211 & 41 & \\
\hline$\geq 12$ & 87 & 38 & \\
\hline Frequency of blood transfusion & & & 0.434 \\
\hline$<2$ & 169 & 42 & \\
\hline$\geq 2$ & 129 & 37 & \\
\hline Amount of blood transfusion (unit) & & & 0.287 \\
\hline$<4$ & 134 & 43 & \\
\hline$\geq 4$ & 164 & 38 & \\
\hline
\end{tabular}


Table 5 Multivariate analysis of patients by Cox model

\begin{tabular}{lllll}
\hline Variable & Wald & P value & RR & $95 \% \mathrm{Cl}$ \\
\hline Gender & 0.419 & 0.518 & 1.056 & $0.895-1.245$ \\
Age & 7.192 & 0.007 & 1.230 & $1.057-1.431$ \\
Tumor location & 9.187 & 0.002 & 0.879 & $0.808-0.955$ \\
TNM stage & 161.018 & $<0.001$ & 3.151 & $2.639-3.762$ \\
Type of gastrectomy & 12.311 & $<0.001$ & 1.403 & $1.161-1.696$ \\
Perioperative blood transfusion & 5.385 & 0.020 & 0.799 & $0.661-0.966$ \\
\hline
\end{tabular}

TNM Tumor Node Metastasis, P value obtained by chi-squares tests or Fisher's exact test, $R R$ relative risk, $C l$ confidence interval

age, tumor location, TNM stage, type of gastrectomy, and perioperative blood transfusion were independent prognostic factors (Table 5). In patients with perioperative blood transfusion, multivariate analysis showed that only TNM stage was independent prognostic factor (Table 6).

\section{Comparison of survival according to perioperative blood transfusion at same stage}

Patients with gastric cancer were analyzed by stage (I, II, or III) and whether they underwent perioperative blood transfusion. Patients with gastric cancer were divided into three stages: stage I, stage II, and stage III. Based on perioperative blood transfusion, each stage was divided into group with perioperative blood transfusion and group without perioperative blood transfusion. There was a significant difference of over-all 5-year survival between group with perioperative blood transfusion and group without perioperative blood transfusion according to stage III $(P<0.001)$ (Fig. 2).

\section{Discussion}

The association between overall prognosis and perioperative blood transfusions has been investigated in several solid tumors [15-20]. However, the results have been inconsistent. Two studies have demonstrated that perioperative blood transfusion was associated with worse clinical outcome in patients undergoing gastrectomy, though other studies have not $[10,11]$. Stefano Rauseiet al.'s study showed that perioperative blood transfusion did not influence the

Table 6 Multivariate analysis of patients with perioperative blood transfusion by Cox model

\begin{tabular}{lllll}
\hline Variable & Wald & $P$ value & RR & $95 \% \mathrm{Cl}$ \\
\hline Gender & 0.839 & 0.360 & 0.859 & $0.621-1.189$ \\
Age & 0.690 & 0.406 & 1.138 & $0.839-1.545$ \\
Tumor location & 0.942 & 0.332 & 0.929 & $0.801-1.078$ \\
TNM stage & 59.565 & $<0.001$ & 3.268 & $2.419-4.415$ \\
\hline
\end{tabular}

TNM Tumor Node Metastasis, $\mathrm{P}$ value obtained by chi-squares tests or Fisher's exact test, $R R$ relative risk, $\mathrm{Cl}$ confidence interval survival of patients with gastric cancer [12]. Moriguchi et al. reported that there was no relationship between perioperative blood transfusion and survival of patients with gastric cancer [13]. Some reasons should be taken into account of the conflicting results. First, influence of perioperative blood transfusion might be coincidental with other factors, which could result in more blood loss and more transfusions. The present study showed that patients with older age, larger tumor size, and more advanced stage were more likely to receive perioperative blood transfusion, which was consistent with other results [21, 22]. Second, most of the published studies were small-size sample, which had small statistic power to get a positive relationship. Therefore, the present study was carried out in a large-scale sample to avoid the above-mentioned limitations.

In this study, perioperative blood transfusions were associated with a worse prognosis in patients with gastric cancer following gastrectomy. Transfusion was an independent prognostic factor confirmed by Cox regression analysis. In subgroup analysis, the difference in overall 5-year survival was significant for patients with Stage III disease, but not Stage I or II. This finding is consistent with results reported by Xue L et al. [23]. Additionally, we analyzed the relationship between frequency of blood transfusion, amount of blood transfusion, and prognosis. Results showed frequency and amount of blood transfusion did not correlate with the survival, which is consistent with other studies $[11,21,24]$. Therefore, it was possible that blood transfusion itself resulted in poor prognosis rather than frequency and amount of blood transfusion. Despite restrictive usage of blood transfusion is recommended by clinical guidelines, perioperative blood transfusion is still overused in clinical practice.

Although the exact mechanism is not clear, immunosuppression may explain the association between worse overall survival and perioperative blood transfusion. Immunosuppresion can be caused by decreased natural killer cell activity and increased suppressor $\mathrm{T}$ lymphocytes activity [25]. Other suppressor factors such as anti-idiotypic antibodies can be produced after receiving blood transfusion [26]. In addition, blood transfusion could promote the proliferation of tumor cells through inducing angiogenesis [27]. This theory was confirmed by Patel et al.' finding that blood transfusion stimulated proliferation and angiogenesis of endothelial cells [28].

Although the present study is one of the largest retrospective studies in China, there are still some limitations in our study. First, we have not analyzed the effect of blood transfusion on postoperative 

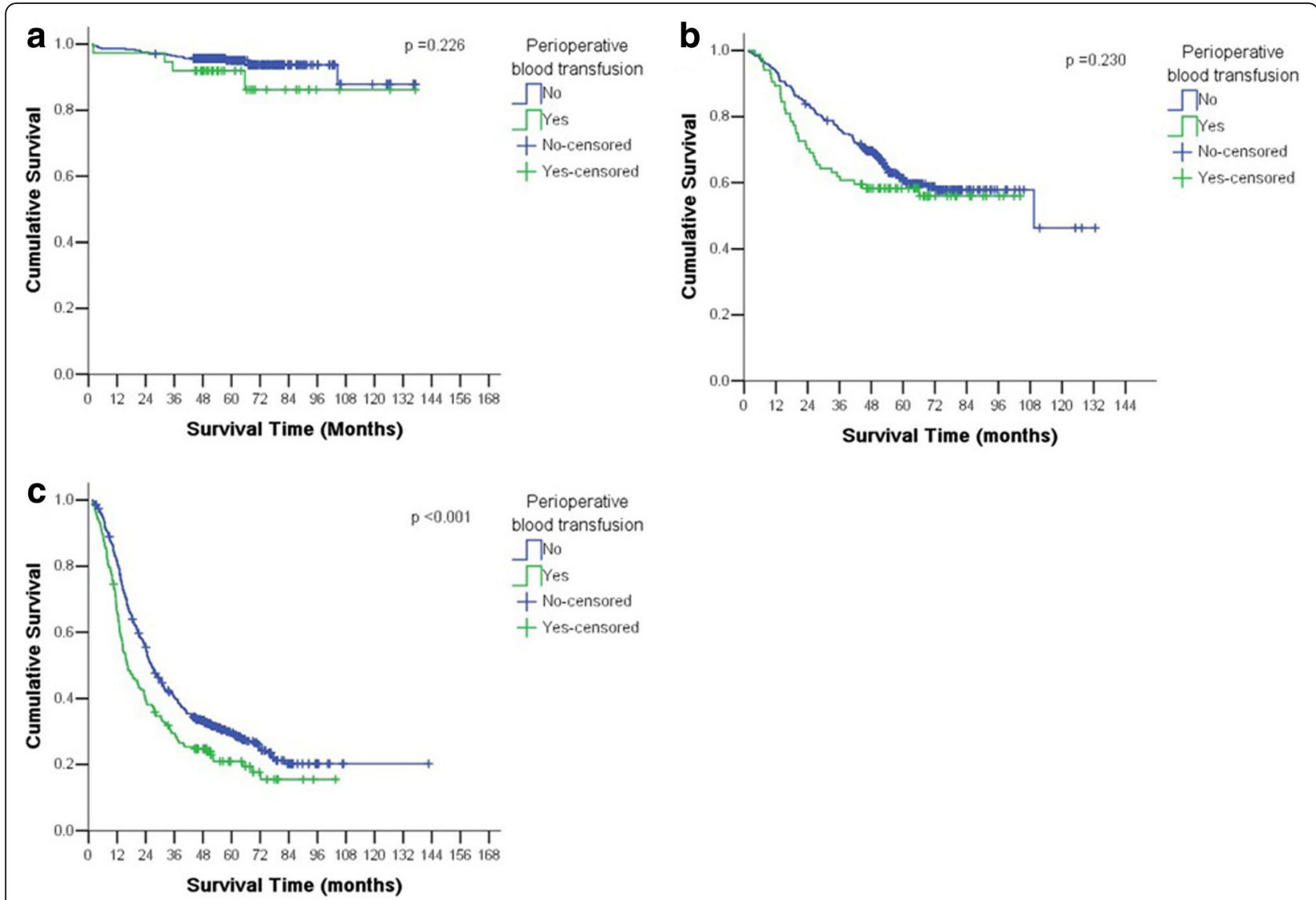

Fig. 2 Comparison of survival according to perioperative blood transfusion in same stage. a There was no significant difference in patients with stage I. b There was no significant difference in patients with stage II. c There was significant difference in patients with stage III

complications and tumor recurrence. Second, adjuvant radiotherapy and chemotherapy were not included into the analysis. Therefore, it is necessary to carry out prospective, randomized, controlled studies to investigate the prognostic effect of blood transfusion in patients with gastric cancer.

\section{Conclusions}

In conclusion, perioperative blood transfusion independently correlated with poorer prognosis in patients with gastric cancer.

\section{Acknowledgements}

The authors thank Hong Cai for assisting in acquisition of data, Ben Liotta for editing our manuscript's English language style, and the patients for their participation in this study.

\section{Funding}

This study was funded by grants from the National Natural Science Foundation of China (81502027), and the Shanghai Committee of Science and Technology Funds (Contract grant numbers: 17411963200). The funders had no role in study design, data collection and analysis, decision to publish, or preparation of manuscript.

\section{Availability of data and materials}

The datasets generated and/or analysed during the current study are not publicly available because they are derived from the patient database of the center and hence subject to confidentiality but are available from the corresponding author on reasonable request.

\section{Authors' contributions}

XWL, MZM and YNW built the conception and designed the study. $\mathrm{HH}$ assisted in acquisition of data. YNW provided administrative support for this study. XWL, MZM and HH provided statistical analysis and interpretation. $X W L$ and MZM wrote, reviewed and revised the manuscript. All authors participated in final approval of the version.

\section{Ethics approval and consent to participate}

The study was approved by the Ethics Committee of the Fudan University Shanghai Cancer Center. All patients provided written informed consent.

\section{Competing interests}

The authors declare that they have no competing interests.

\section{Publisher's Note}

Springer Nature remains neutral with regard to jurisdictional claims in published maps and institutional affiliations.

Received: 17 January 2018 Accepted: 1 June 2018 Published online: 11 June 2018

\section{References}

1. Torre LA, Bray F, Siegel RL, Ferlay J, Lortet-Tieulent J, Jemal A. Global cancer statistics, 2012. CA Cancer J Clin. 2015;65:87-108.

2. Wanebo HJ, Kennedy BJ, Chmiel J, et al. Cancer of the stomach: a patient care study by the American College of Surgeons. Ann Surg. 1993;218:583-92. 
3. Grotto HZ. Anaemia of cancer: an overview of mechanisms involved in its pathogenesis. Med Oncol. 2008;25:12-21.

4. Ludwig H, Van Belle S, Barrett-Lee P, et al. The European Cancer Anaemia survey (ECAS): a large, multinational, prospective survey defining the prevalence, incidence, and treatment of anaemia in cancer patients. Eur J Cancer. 2004:40:2293-306.

5. Hill GE, Frawley WH, Griffith $\mathrm{KE}$, et al. Allogeneic blood transfusion increases the risk of postoperative bacterial infection: a meta-analysis. J Trauma. 2003;54:908-14

6. Fisahn C, Jeyamohan S, Norvell DC, et al. Association between allogeneic blood transfusion and postoperative infection in major spine surgery. Clin Spine Surg. 2017;30:E988-92

7. Hyman NH, Foster RS Jr, DeMeules JE, Costanza MC. Blood transfusions and survival after lung cancer resection. Am J Surg. 1985;149:502-7.

8. Tartter PI, Burrows L, Papatestas AE, Lesnick G, Aufses AH Jr. Perioperative blood transfusion has prognostic significance for breast cancer. Surgery. 1985;97:225-30

9. Talukder Y, Stillwell AP, Siu SK, Ho YH. Comparing survival and recurrence in curative stage I to III colorectal cancer in transfused and nontransfused patients. Int Surg. 2014;99:8-16

10. Li L, Zhu D, Chen X, Huang Y, Ouyang M, Zhang W. Perioperative Allogenenic blood transfusion is associated with worse clinical outcome for patients undergoing GastricCarcinoma surgery: a meta-analysis. Medicine. 2015;94:e1574.

11. Ojima T, Iwahashi M, Nakamori M, Nakamura M, Naka T, Katsuda M, lida T, Hayata K, Yamaue $\mathrm{H}$. Association of allogeneic blood transfusions and longterm survival of patients with gastric cancer after curative gastrectomy. J Gastrointest Surg. 2009;13:1821-30.

12. Rausei S, Ruspi L, Galli F, Tirotta F, Inversini D, Frattini F, Chiappa C, Rovera F, Boni L, Dionigi G, Dionigi R. Peri-operative blood transfusion in gastric cancer surgery: prognostic or confounding factor? Int J Surg. 2013;11(Suppl 1):S100-3.

13. Moriguchi S, Maehara Y, Akazawa K, Sugimachi K, Nose Y. Lack of relationship between perioperative blood transfusion and survival time after curative resection for gastric cancer. Cancer. 1990;66:2331-5.

14. Liu $X$, Cai H, Huang H, Long Z, Shi Y, Wang Y. The prognostic significance of apoptosis-related biological markers in Chinese gastric cancer patients. PLoS One. 2011;6:e29670.

15. Crowe JP, Gordon NH, Fry DE, et al. Breast cancer survival and perioperative blood transfusion. Surgery. 1989;106:836-41.

16. Garona J, Sobol NT, Alonso DF. Impact of Perioperative Blood Transfusion on Survival Among Women With Breast Cancer: Potential Benefits of BloodSaving Agent Desmopressin Use During Surgery. Am J Ther. 2017; https:// doi.org/10.1097/MJT. 0000000000000647.

17. Owusu-Agyemang P, Zavala AM, Williams UU, Van Meter A, Soliz J, Kapoor R, Shah A, Hernandez M, Gottumukkala V, Cata JP. Assessing the impact of perioperative blood transfusions on the survival of adults undergoing cytoreductive surgery with hyperthermic intraperitoneal chemotherapy for appendiceal carcinomatosis. Vox Sang. 2017;112:567-77.

18. Poorman CE, Postlewait LM, Ethun CG, Tran TB, Prescott JD, Pawlik TM, Wang TS, Glenn J, Hatzaras I, Shenoy R, Phay JE, Keplinger K, Fields RC, Jin LX, Weber SM, Salem A, Sicklick JK, Gad S, Yopp AC, Mansour JC, Duh QY, Seiser N, Solorzano CC, Kiernan CM, Votanopoulos KI, Levine EA, Staley CA, Poultsides GA, Maithel SK. Blood Transfusion and Survival for Resected Adrenocortical Carcinoma: A Study from the United States Adrenocortical Carcinoma Group. Am Surg. 2017;83:761-8.

19. Tzounakas VL, Seghatchian J, Grouzi E, Kokoris S, Antonelou MH. Red blood cell transfusion in surgical cancer patients: Targets, risks, mechanistic understanding and further therapeutic opportunities. Transfus Apher Sci. 2017;56:291-304

20. Amri R, Dinaux AM, Leijssen LGJ, Kunitake H, Bordeianou LG, Berger DL. Do packed red blood cell transfusions really worsen oncologic outcomes in colon cancer? Surgery. 2017;162:586-91.

21. Kanda M, Kobayashi D, Tanaka C, Iwata N, Yamada S, Fujii T, Nakayama G, Sugimoto H, Koike M, Nomoto S, Murotani K, Fujiwara M, Kodera Y. Adverse prognostic impact of perioperative allogeneictransfusion on patients with stage II/III gastric cancer. Gastric Cancer. 2016;19:255-63.

22. Wu G, Zhang DY, Duan YH, Zhang YQ, Cui XN, Luo Z. Correlations of hemoglobin level and perioperative blood transfusion with the prognosis of gastric cancer: a retrospective study. Med SciMonit. 2017;23:2470-8.

23. Xue $L$, Chen $X L$, Wei-Han Z, Yang $K$, Chen XZ, Zhang B, Chen ZX, Chen JP, Zhou ZG, Hu JK. Impact of perioperative blood transfusion on postoperative complications and prognosis of gastric adenocarcinoma patients with different preoperative hemoglobin value. Gatroenterol Res Pract. 2016;2016: 6470857.

24. Kim SH, Lee SI, Noh SM. Prognostic significance of preoperative blood transfusion in stomach cancer. J Gastric Cancer. 2010;10:196-205.

25. Grzelak I, Zaleska M, Olszewski WL. Blood transfusion downregulate hematopoiesis and subsequently downregulate the immune response. Transfusion. 1998;38:1104-14.

26. Wu HS, Little AG. Perioperative blood transfusions and cancer recurrence. J Clin Oncol. 1988;6:1348-54

27. Zhou HY, Yi W, Wang J, Zhang J, Wang WJ, Hu ZQ. Association of perioperative allogeneic blood transfusion and prognosis of patients with gastric cancer after curative gastrectomy. Am J Surg. 2014;208:80-7.

28. Patel HB, Nasir FA, Nash GF, Scully MF, Kakkar AK. Enhanced angiogenesis following allogeneic blood transfusion. Clin Lab Haematol. 2004;26:129-35.

\section{Ready to submit your research? Choose BMC and benefit from:}

- fast, convenient online submission

- thorough peer review by experienced researchers in your field

- rapid publication on acceptance

- support for research data, including large and complex data types

- gold Open Access which fosters wider collaboration and increased citations

- maximum visibility for your research: over $100 \mathrm{M}$ website views per year

At BMC, research is always in progress.

Learn more biomedcentral.com/submissions 